\title{
Individual Counseling Program of Islamic Vocational High School in Indonesia
}

\author{
W. N. E. Saputra \& Syamsudin \\ Universitas Ahmad Dahlan, Yogyakarta, Indonesia
}

\author{
P. S. Rohmadheny \\ BAN PAUD \& PNF, Jakarta, Indonesia
}

\begin{abstract}
This study is an evaluation research using discrepancy model, which aims to describe the discrepancy of level in the aspects of planning, implementation and evaluation in implementing individual counseling programs in schools with defined standards and criteria. This research uses mixed method design with concurrent triangulation model. The collected data is analyzed by quantitative technique through comparative constant and comparative modified test and qualitative technique with the meaning of data. The results showed that the implementation of individual counseling programs in four schools studied was at the level nearly meet the standards. In particular, the combined profile results also indicate that the individual counseling program planning aspect is at the level nearly meet the standards. Moreover, the aspect of individual counseling program implementation is also at the level nearly meet the standards. However, the evaluation aspect of the individual counseling program showed that it is at the standard level.
\end{abstract}

\section{Keywords: counseling, Islamic Vocational School}

\section{INTRODUCTION}

Guidance and counseling program in Indonesia is carried out through comprehensive patterns. It is designed in four fields, those are guidance curriculum, individual planning, responsive services, and system support (Gysbers\& Henderson, 20014; Gysbers, 2008; Gysbers et al., 2008). Counseling service is the core of comprehensive guidance and counseling services (Gibson \& Mitchell, 2011), especially individual counseling. Therefore, counselors need to design a program to meet the requirements of the individual counseling services. Sherwood (2010) concludes that counselors have the understanding of the purposes of the individual counseling program at school, which is to fulfill the needs of the school and the students, thereby giving positive changes to students' behavior. In this program, counselors need to design a program that covers planning, implementation, and evaluation of the program (Winkel, 1991).

As the core of guidance and counseling services, the quality of the individual counseling program relies on the implementer. Counselors are those who have the abilities and skills to carry out individual counseling services. School counselors, as professional in implementing guidance and counseling services, should carry out the program professionally. The research findings of Mellin, Hunt, \& Nichols (2011) showed that counselors need to have a professional identity. Counselors should be able to distinguish counseling profession from psychology or any other social works.

The ideal condition cannot be fully implemented. In general, Saputra (2015) concludes that the implementation of the counseling program in Junior High Schools in Malang has not met the standards. The evaluation conducted by Saputra (2016a) in one of the Junior High Schools in Malang mentions that the individual counseling program has not reached the standards. Saputra (2016b) founds similar results in his further evaluation of group counseling program at the same schools in Malang. The phenomena show the disparity between the standards as well as the criteria and the real condition. Thus, counselors need to take some efforts to anticipate the gaps, especially in the individual counseling program. One of them is by evaluating the program to improve the quality of individual counseling program professionally.

One of the evaluation models to be applied in evaluating individual counseling program is the discrepancy model. Provus explains that discrepancy model aims to know the appropriateness level between the standards and the actual performance (McKenna, 1981). The standards and the criteria are in accordance with the Guidelines for Performance-Based Professional School Counselor Evaluation (Missouri Department of Elementary and Secondary Education, 2000). The standard evaluation of counseling services is in standard 3 criteria 5, stating that "professional school counseling carries out the services to students whose needs and problems have been identified, both individually and in a group." This study attempts to evaluate individual counseling program of Islamic vocational high school in Indonesia. Despite it's the core of guidance and counseling program, individual counseling should be identified in effect of changes in the behavior of the counselees.

\section{METHOD}

This study belongs to evaluation research using discrepancy model in order to describe the disparity level on the aspects of planning, implementation, and evaluation of individual counseling program at schools, according to particular standards and criteria. The process of this study includes (1) an agreement on particular standards; (2) the disparity between the performance and several aspects of the program and the standard devices for the performance; and (3) the use of the information about the disparity in the decision to develop, to continue, or to stop the whole program or one of the aspects of the program (Fitzpatrick, Sanders, \&Worthen, 
2004). This research uses system approach focused on the planning, implementation, and evaluation of the individual counseling program. Subjects in this study were four counselors as the primary subject and eight students as the secondary subjects at Muhammadiyah vocational high school in Yogyakarta City. It is one of an Islamic vocational high school in Yogyakarta, Indonesia.

The research applies mixed method design, which is a combination of quantitative (questionnaire and documentation) and qualitative (interview) instruments, with concurrent triangulation model to confirm the data. Questioners, documentation, and interviews are used to identify the planning, implementation, and evaluation of individual counseling programs. The instrument is aimed at the counselor as the primary subject and the student to confirm the truth of the data from the counselor. The obtained data are analyzed using a quantitative technique with constant comparative and modified comparative test as well as the qualitative technique by interpreting the data.

\section{RESULTS AND DISCUSSION}

The results based on Modified Comparative analysis can be explained as follow. First, the comparison between the implementation of the individual counseling program in SMK Muhammadiyah A and B (Profile I) show $\mathrm{T}_{\text {observe }}$ of 0.172 $\left(<\mathrm{T}_{\text {table }}\right.$ of 3.182). This finding means that the implementation of the individual counseling program in SMA Muhammadiyah A and B is similar. Second, the comparison between the implementation of individual counseling of Profile I and SMK Muhammadiyah C (Profile II) show $\mathrm{T}_{\text {observe }}$ of $0.059\left(<\mathrm{T}_{\text {table }}\right.$ of 3.182). In the same way, the individual counseling program in Profile I and SMA Muhammadiyah $\mathrm{C}$ is similar. Third, the comparison between the implementation of the program in Profile II and SMK Muhammadiyah D (Profile III) show $\mathrm{T}_{\text {observe }}$ of $0.095\left(<\mathrm{T}_{\text {table }}\right.$ of 3.182$)$, which results in similar findings with the previous comparative analysis.

While the constant comparative analysis results in the following. In Constant I, the mean is 0.00006 , bigger than the mean of combined profiles of sample school, reaching 0.00003 . It means that there is no disparity between the implementation of the individual counseling program in SMK Muhammadiyah A and combined profiles of sample school. In Constant II, the mean is 0.000003 , less than the mean of the combined profile of sample school, which reaches 0.0003 . It means that there is a disparity between the implementation of the individual counseling program in SMK Muhammmadiyah $B$ with the specified standards (combined profiles of sample school). In Constant III, the mean is 0.019967 , bigger than the mean of combined profiles of sample schools, reaching 0.00003 , which means that there is no disparity between the implementation of the program in SMK Muhammadiyah C and the specified standards (combined profiles of sample schools). In Constant IV, the disparity is found between the implementation of the program in SMK Muhammadiyah D and the specified standards, giving the mean of -0.0000027 , less than the mean of combined profiles of sample schools, reaching 0.00003 .

In general, the results of the research show that the implementation of the individual counseling program in the selected schools is close to the specified standards, reaching $71.88 \%$. In particular, the combined profile also indicates that the aspect of planning in the individual counseling also nearly meets the standards, reaching $70.09 \%$. Similarly, the implementation and evaluation aspect of the program also reaches the specified standards with the score of $69,16 \%$ and $80,64 \%$, respectively. The evaluation of the implementation provides the information to verify the strengths and weaknesses of counseling services (Otto, 2001). One of the benefits of conducting the evaluation is as a consideration in the decision to develop, continue, or discontinue the whole program or one of the aspects of the program (Fitzpatrick, Sanders, \&Worthen, 2004).

The research shows that the implementation of individual counseling program has not fulfilled the specified standards. The results are in accordance with the findings of other studies. The research conducted by Saputra (2015) indicates that the counseling program in Junior High Schools in Malang is far below the standards. The results of the research provide a recommendation for the counselors to improve the quality of the counseling program for the betterment of the students.

Saputra (2016a), with the evaluation research using discrepancy model to see the disparity between the performance of individual counseling and the specified standards, show that individual counseling program in SMP Laboratorium of Malang State University has not fulfilled the specified standards. In details, it can be described as follow: (a) 54,6\% of the aspects of the program activities have been properly implemented; (b) $9,1 \%$ of the aspects of the program activities have partially implemented; and (c) $36,4 \%$ of the aspects have not been implemented at all. The research also recommends the counselor improve the quality of the program in order to give positive impact to the students.

Similarly, in his next study, Saputra (2016b) carried out an evaluation research with discrepancy model to see the disparity between group counseling program and the specified standards. According to the data analysis, the groupcounseling program in SMP Laboratorium of Malang State University has not fulfilled the standards. In details, it can be described as follow: (a) $51,1 \%$ of the aspects in group counseling program activities have been properly implemented; (b) $17,8 \%$ of the aspects are partially implemented; and (c) $31,1 \%$ of the aspects of the program have not been implemented.

The disparity between the performances of individual counseling program with the standards is caused by several reasons. First is the less professional program as the result of low competence level of the counselors at school (Jacobs, et al., 2013; Rust, Raskin \& Hill, 2013). Counselors, as professionals, seem not to have the capabilities to manage four professional fields of individual counseling program (personal, career, academic, and social). It is evident in their lack of 
mastery in implementing the program. Therefore, Swank, Lambie, and Witta (2012) created an instrument that can be used to measure the level of counselor's professional competence called counseling competence scale.

Second, the counselee's unwillingness to consult with counselors in individual counseling is caused by the latter's incapability to create a quality session with the students. The session between counselors and students are not different from a regular meeting between them.

So, the counselors need to have counseling skills, because counselor skills had an indirect effect on behavior changes of counselee's (Lindqvist, et al., 2017). Counselors with good counseling communication competence will bring better changes to counselees' behavior. (Gaume, et al, 2010).

Third, the implementation of individual counseling program has not fulfilled the standards. In accordance with the findings, it is assumed that the situation is caused by loose supervision. The study conducted by DeKruyf \& Pehrsson (2011) show that $54 \%$ of counseling supervisors at schools only have little or have never taken counseling supervision training. Barriers to implementation of supervision include lack of consensus on effective supervision practices, lack of empirical support for the model, and an absence of systematic training in clinical supervision during the training trajectory (Falender \& Shafranske, 2017). The activities, based on the research by Moyer (2011), will result in school counselor burnout.

Supervision for individual counseling program at the school is rarely conducted. In fact, the headmaster, as the policy-maker, rarely takes their responsibility as a supervisor. However, headmaster can take one effort in doing the supervision. Self-supervision helps counselors to know the significance of their contribution to the implemented program, thereby guiding them to do some improvements (Hawkins \& Shobet, 2007). Self-supervision is closely related to the habit of self-reflection. Peer supervision can also become the alternative. As teamwork and colleague, counselors in one school support each other by giving suggestions and assessment on each other's performance (Proctor, 2008). The internalization of self-supervision and peer supervision in every counselor should be supported by the headmaster as the policy-maker at school, thereby providing the opportunities to supervise the program of guidance and counseling, especially individual counseling (Wosket, 2002).

The real condition shows that counselors are reluctant to do self-reflection. Counselors are overconfident that they have provided maximum services during the implementation of the program. The attitude is originated from the counselors' assumption on the low frequency of students' consulting their problem (Davys \&Beddoe, 2010). It is also evident in students' unwillingness to consult with counselors, especially for additional counseling services because they do not find any change or progress.

Low self-reflection conducted by the counselors is influenced by several factors. First, the counselors only look at their experiences to guarantee the quality and success of the program. The second is the counselors' nervousness on their professional status that draws them back from any progress. Indeed, counselors are required to reflect their every service. The performance of school counselor in implementing the program is evident in the students' behavioral changes (Astramovich\& Coker, 2007).

\section{CONCLUSION}

The research shows that the implementation of the individual counseling program in the four selected schools nearly meet the standards. This is a reflection for school counselors to highlight individual counseling programs with the maximum. So that changes in student behavior as an indicator of individual counseling programs can be achieved successfully.

\section{REFERENCES}

Astramovich, R.L. \& Coker, J.K. 2007.Program Evaluation: The Accountability Bridge Model for Counselors.Journal of Counseling \& Development, 85: 162-172.

Davys, A., \&Beddoe, L. 2010. Best Practice in Professional Supervision: A Guide for The Helping Professions. London: Jessica Kingsley Publisher.

DeKruyf, L., \&Pehrsson, D. E. 2011. School counseling site supervisor training: An exploratory study. Counselor Education and Supervision, 50 (5): 314-327.

Falender, C.A. \&Shafranske, E.P., 2017.Competency- based Clinical Supervision: Status, Opportunities, Tensions, and the Future. Australian Psychologist, 52 (2): 86-93.

Fitzpatrick L. J., Sanders R. J., \&Worthen R. B. 2004. Program Evaluation Alternative Approaches and Guidelines.USA: Pearson Education, Inc.

Gaume, J., Bertholet, N., Faouzi, M., Gmel, G., \&Daeppen, J. B. 2010. Counselor motivational interviewing skills and young adult change talk articulation during brief motivational interventions. Journal of substance abuse treatment, 39 (3): 272-281.

Gibson, R. L., \& Mitchel, M. H. 2011.BimbingandanKonseling.Translation: YudiSantoso. Yogyakarta: PustakaPelajar.

Gysbers, N. C., \& Henderson, P. 2014. Developing and managing your school guidance and counseling program. John Wiley \& Sons.

Gysbers, C. N. 2008. Individual Student Planning in the United States: Rationale, Practices, and Results.Asian Journal of Counselling, 15 (2): 117-139.

Gysbers, N. C., Stanley, J. B., Kosteck-Bunch, L., Magnuson, C. S., \& Starr, M. F. 2008. Missouri comprehensive guidance program: A manual for program development, implementation, evaluation and enhancement. Warrensburg, MO: Missouri Center for Career Education.

Hawkins, P., \&Shobet, R. 2007. Supervision in the Helping Professions.Brekshire: McGraw Hill, Open University Press.

Jacobs, S. C., Huprich, S. K., Grus, C. L., Cage, E. A., Elman, N. S., Forrest, L., ... \&Kaslow, N. J. 2011. Trainees with professional competency problems: Preparing trainers for 
difficult but necessary conversations. Training and Education in Professional Psychology, 5 (3): 175-184.

Lindqvist, H., Forsberg, L., Enebrink, P., Andersson, G., \&Rosendahl, I., 2017. The relationship between counselors' technical skills, clients' in-session verbal responses, and outcome in smoking cessation treatment. Journal of Substance Abuse Treatment, 77: 141149.

McKenna, C. 1981. Making Evaluation Manageable.Journal of Extention, 1-14.

Mellin, E. A., Hunt, B., \& Nichols, L. M. (2011).Counselor professional identity: Findings and implications for counseling and interprofessional collaboration. Journal of Counseling \& Development, 89 (2): 140-147.

Missouri Department of Elementary and Secondary Education.2000. Guidelines for Performancebased Professional School Counselor Evaluation.Jefferson City, MO: Author.

Moyer, M. 2011. Effects of Non-Guidance Activities, Supervision, and Student-to-Counselor Ratios on School Counselor Burnout. Journal of School Counseling, 9(5).

Otto, C. N. C. 2001.An Evaluation of the School Counseling Program at Stillwater Area Schools in Stillwater, Minnesota. University of Wisconsin-Stout: The Graduate College.

Proctor, B. 2008.Group Supervision: A Guide to Creative Practice.London: Sage Publications.

Rust, J. P., Raskin, J. D., \& Hill, M. S. 2013. Problems of professional competence among counselor trainees: Programmatic issues and guidelines. Counselor Education and Supervision, 52 (1): 30-42.
Saputra, W. N. E. 2015. Evaluasi Program Konseling di SMP kota Malang: Discrepancy Model. JurnalPsikologiPendidikan\&Konseling, 1 (2): 180-187.

Saputra, W. N. E. 2016a. Evaluasi Program KonselingIndividu di SMP LaboratoriumUniversitasNegeri Malang dengan Model Discrepancy.JurnalFokusKonseling, 2 (1): 1-10.

Saputra, W. N. E. 2016. Evaluation of Group Counseling Program on SMP LaboratoriumUniversitasNegeri Malang: Discrepancy Model.JurnalGuidena, 6 (1): 11-17.

Sherwood, H. 2010. A School Counseling Program Evaluation: Utilizing Staff Perceptions to Guide and Shape Future Program Planning.Georgia School Counselors Association Journal, 17 (1): 15-25.

Swank, J. M., Lambie, G. W., \&Witta, E. L. 2012.An exploratory investigation of the Counseling Competencies Scale: A measure of counseling skills, dispositions, and behaviors. Counselor Education and Supervision, 51 (3): 189-206.

Winkel, W. S. 1991. BimbinganKonseling di SekolahMenengah.Jakarta: Grasiondo.

Wosket, V. 2002.The Therapeutic Use of Self: Counseling Practice, Research and Supervision.London: Routledge. 